\title{
Maternal haemoglobin and perinatal outcome in a tertiary care hospital in Jammu city, India
}

\author{
Indu Kaul, Isha Sunil*, Aakriti Gupta
}

Department of Obstetrics and Gynecology, GMC, Jammu, Jammu and Kashmir, India

Received: 01 September 2017

Accepted: 25 September 2017

*Correspondence:

Dr. Isha Sunil,

E-mail: isha3487@gmail.com

Copyright: () the author(s), publisher and licensee Medip Academy. This is an open-access article distributed under the terms of the Creative Commons Attribution Non-Commercial License, which permits unrestricted non-commercial use, distribution, and reproduction in any medium, provided the original work is properly cited.

\begin{abstract}
Background: Maternal anemia is a common problem worldwide. The objective of this study was to assess the prevalence of anemia in women attending a tertiary care centre in their third trimester of pregnancy and to study the relation of maternal hemoglobin with perinatal outcome.

Methods: This study was conducted in the Department of Obstetrics and Gynecology, SMGS Hospital, Jammu for a period of one year from Nov. 2015 to Oct. 2016. A total of 767 women in their third trimester (>28 weeks) were enrolled and were followed till delivery. Their hemoglobin levels were noted and its association with adverse maternal and fetal outcomes was studied.

Results: It was seen that out of 767 patients, $193(25.16 \%)$ were non-anemic and $574(74.83 \%)$ were anemic out of which $343(44.71 \%)$ were mildly anemic, 160 (20.86\%) had moderate anemia and $70(9.12 \%)$ had severe anemia. There was increased incidence of preterm delivery, PPH, preeclampsia, eclampsia, CCF, mortality \& blood transfusions in the anemic group as compared to the non-anemic group. Among the adverse fetal outcomes, there was increased incidence of intrauterine deaths, intrauterine growth restriction, NICU admissions, meconium stained liquor, low birth weight babies and APGAR scores <7/10 among the anemic group as compared to the non-anemic group.

Conclusions: Maternal anemia is a significant risk factor for adverse maternal and perinatal outcome and its prevalence continues to be high especially in developing countries like India. So, correction of maternal anemia still remains one of the most important step towards better obstetrical care.
\end{abstract}

Keywords: Anemia, Intrauterine growth restriction, Preterm birth, PPH, Preeclampsia

\section{INTRODUCTION}

Anemia is defined as a condition of low circulatory hemoglobin in which hemoglobin concentration has fallen below the threshold lying at 2SD below the median of a healthy population of same age and stage of pregnancy. ${ }^{1}$ According to World Health Organization (WHO), anemia in pregnancy is defined as hemoglobin concentration $<11 \mathrm{gm} \%$ and further categorized into three levels
- Mild: $9-10.9 \mathrm{gm} / \mathrm{dl}$

- Moderate: $7-8.9 \mathrm{gm} / \mathrm{dl}$

- Severe: $<7 \mathrm{gm} / \mathrm{dl} .^{2}$

Maternal anemia is a common problem worldwide. According to the $2008 \mathrm{WHO}$ analysis, anemia affected $24.8 \%$ of the world's population. In India, in one of the studies conducted on a large population, it was estimated that $87 \%$ of the women are anemic. ${ }^{3}$ 
Maternal anemia in pregnancy is commonly considered as risk factor for poor pregnancy outcomes and can threaten the life of mother and fetus. ${ }^{4}$ Studies have documented a strong association between low hemoglobin before delivery and adverse outcomes. ${ }^{5}$ Antepartum complications associated or aggravated by anemia are pre-eclampsia, antepartum hemorrhage, preterm deliveries and maternal mortality. ${ }^{6}$ Maternal anemia is also considered a risk factor for poor perinatal outcome like low birth weight babies, low APGAR scores at one min, meconium stained liquor and NICU admissions. $^{7}$

So, the aim of present study was to evaluate the impact of maternal anemia on various perinatal outcomes in our hospital.

\section{METHODS}

This study was conducted in the Department of Obstetrics and Gynecology, SMGS Hospital, Government Medical College, Jammu for a period of one year from November 2015 to October 2016.

A total of 767 women in their third trimester ( $>28$ weeks of gestation) were enrolled after briefing them about the purpose of the study. These were followed till delivery.

\section{Inclusion criteria}

- Women attending Government Medical college in their third trimester ( $>28$ weeks)

- Singleton pregnancy

- Age 18 years and above

\section{Exclusion criteria}

- Multiple pregnancies

- Other associated medical complications

- Antepartam hemorrhage

- Anemia due to acute blood loss.

All the participants were subjected to thorough history and general physical and systemic examinations.

The following investigations were carried out: CBC, Red Blood Indices, Iron studies.

Subjects were then categorized into following groups depending upon hemoglobin level according to WHO standards:

- Non-anemic: $>11 \mathrm{gm} / \mathrm{dl}$

- $\quad$ Mild: $9-10.9 \mathrm{gm} / \mathrm{dl}$

- Moderate: $7-8.9 \mathrm{gm} / \mathrm{dl}$

- $\quad$ Severe: $<7 \mathrm{gm} / \mathrm{dl}$ of: Meconium stained liquor, Low birth weight, APGAR
Adverse perinatal outcome was measured as occurrence

score $<7 / 10$, Intrauterine growth restriction, Admission in NICU, Intrauterine death

Adverse maternal outcome was measured as occurrence of: Preterm delivery, Preeclampsia, Blood transfusions, $\mathrm{PPH}$, Congestive cardiac failiure, Maternal mortality.

\section{Statistical analysis}

Pearson's Chi-squared test was used to test the difference between two categorical variables and the level of significance was determined by calculating $p$-value for various maternal and perinatal outcomes in the anemic and non-anemic group. Student t-test was used to determine the mean and standard deviation values for the mean birth weight, APGAR scores at birth etc.

\section{RESULTS}

Table 1 shows that out of 767 patients, $193(25.16 \%)$ were non-anemic and $574(74.83 \%)$ were anemic out of which $343(44.71 \%)$ were mildly anemic, 160 (20.86\%) had moderate anemia and $70(9.12 \%)$ had severe anemia.

Table 1: Distribution of patients according to hemoglobin levels.

\begin{tabular}{|c|c|c|c|c|}
\hline $\begin{array}{l}\text { Anemia } \\
\text { (Hb g\%) }\end{array}$ & $\begin{array}{l}\text { No. of } \\
\text { patients }\end{array}$ & $\%$ & p-value & Remarks \\
\hline Severe $(<7 \%)$ & 70 & 9.12 & \multirow{4}{*}{$<0.0001$} & \multirow{4}{*}{$\mathrm{S}$} \\
\hline $\begin{array}{l}\text { Moderate } \\
(7-8.9 \%)\end{array}$ & 160 & 20.86 & & \\
\hline $\begin{array}{l}\text { Mild } \\
(9-10.9 \%)\end{array}$ & 344 & 44.71 & & \\
\hline $\begin{array}{l}\text { Non-anemic } \\
(>11 \%)\end{array}$ & 193 & 25.16 & & \\
\hline
\end{tabular}

Table 2 shows that among the anemic patients, there were 10 cases $(1.74 \%)$ in the age group <20 years, 296 $(51.57 \%)$ in $20-25$ years, $211(36.76 \%)$ in $25-30$ years, $42(7.32 \%)$ in $30-35$ years, and $15(2.61 \%)$ in age group $>35$ years. Among the non-anemic, 6 cases $(3.11 \%)$ were $<20$ years, $98(50.78 \%)$ in 20-25 years age group, 66 $(34.20 \%)$ in $25-30$ years age group, 17 (8.81\%) in age group $30-35$ years and $6(3.11 \%)$ above 35 years age.

Table 2: Distribution of patients according to age.

\begin{tabular}{|c|c|c|c|c|}
\hline \multirow{3}{*}{$\begin{array}{l}\text { Age } \\
\text { (years) }\end{array}$} & \multicolumn{4}{|c|}{ No. of patients } \\
\hline & \multicolumn{2}{|c|}{ Anemic $(n=574)$} & \multicolumn{2}{|c|}{ Non-anemic $(n=193)$} \\
\hline & No. & $\%$ & No. & $\%$ \\
\hline$<20$ & 10 & 1.74 & 6 & 3.11 \\
\hline $20-25$ & 296 & 51.57 & 98 & 50.78 \\
\hline $25-30$ & 211 & 36.76 & 66 & 34.20 \\
\hline $30-35$ & 42 & 7.32 & 17 & 8.81 \\
\hline$>35$ & 15 & 2.61 & 6 & 3.11 \\
\hline Mean age & \multicolumn{2}{|c|}{$25.84 \pm 4.02$} & \multicolumn{2}{|c|}{$25.91 \pm 4.19$} \\
\hline p-value & \multicolumn{4}{|c|}{0.838} \\
\hline Remarks & \multicolumn{4}{|l|}{ NS } \\
\hline
\end{tabular}


Table 3: Group comparison of anemic patients according to gravidity.

\begin{tabular}{|c|c|c|c|c|c|c|c|}
\hline \multirow{2}{*}{ Obstetrical History } & \multirow{2}{*}{ No. } & \multicolumn{2}{|c|}{ Multigravida } & \multicolumn{2}{|c|}{ Primigravida } & \multirow[t]{2}{*}{ p-value } & \multirow[t]{2}{*}{ Remarks } \\
\hline & & No. & $\%$ & No. & $\%$ & & \\
\hline Mild anemia & 344 & 232 & 67.44 & 112 & 32.55 & $<0.0001$ & $\mathrm{~S}$ \\
\hline Moderate anemia & 160 & 111 & 69.37 & 49 & 30.62 & $<0.0001$ & $\mathrm{~S}$ \\
\hline Severe anemia & 70 & 55 & 78.57 & 15 & 21.42 & $<0.0001$ & $\mathrm{~S}$ \\
\hline Total Anemic & 574 & 398 & 69.33 & 176 & 30.66 & $<0.0001$ & $\mathrm{~S}$ \\
\hline
\end{tabular}

NS = Non-significant, $\mathrm{S}=$ Significant

The mean age in the anemic group was $25.84 \pm 4.02$ while in the non-anemic group it was $25.91 \pm 4.19$ which was statistically non-significant.

Table 3 shows the distribution of the anemic patients according to their parity. Among the patients with mild anemia, 232 cases i.e. $67.44 \%$ were multigravida and 112 cases i.e. $32.55 \%$ were primigravida. In the moderately anemic group, 111 cases $(69.37 \%)$ were multigravida and 49 cases i.e. $30.62 \%$ were primigravida. Among the cases with severe anemia, 55 cases i.e. $78.57 \%$ were mutigravida and 15 cases i.e. $21.42 \%$ were primigravida.

Table 4: PBF examination among the anemic and non-anemic patients.

\begin{tabular}{|c|c|c|c|c|}
\hline \multirow{2}{*}{ PBF } & \multicolumn{2}{|c|}{ No. of patients (\%) } & \multirow{2}{*}{ p-value } & \multirow{2}{*}{ Remarks } \\
\hline & Anemic $(n=574)$ & Non-anemic $(n=193)$ & & \\
\hline Normocytic normochromic & $256(44.59)$ & $146(75.65)$ & $<0.0001$ & $\mathrm{~S}$ \\
\hline Microcytic Hypochromic & $273(47.56)$ & $47(24.35)$ & $<0.0001$ & $\mathrm{~S}$ \\
\hline Macrocytic & $42(7.32)$ & $0(0.00)$ & $<0.01$ & $\mathrm{~S}$ \\
\hline Dimorphic & $3(0.52)$ & $0(0.00)$ & 0.684 & NS \\
\hline
\end{tabular}

NS = Non-significant, $\mathrm{S}=$ Significant

Table 4 shows the distribution of patients according to PBF. 256 anemic cases i.e. 44.59\% showed Normocytic normochromic blood picture, 273 cases i.e. $47.56 \%$ showed Microcytic Hypochromic blood picture, 42 cases i.e. $7.32 \%$ showed macrocytic blood picture and 3 cases i.e. $0.52 \%$ showed Dimorphc blood picture on PBF.
Among the non-anemic patients, 146 patients i.e. $75.65 \%$ showed Normocytic normochromic blood picture, 47 cases i.e. 24.35\% showed Microcytic Hypochromic blood picture, 0 cases i.e. showed macrocytic blood picture and none had Dimorphc blood picture on PBF.

Table 5: Comparison of anemic and non-anemic group for red cell indices.

\begin{tabular}{|lllll|}
\hline Variables & Mean \pm SD & & p-value & Remarks \\
\hline MCV (fL) & Anemic $(\mathbf{n = 5 7 4 )}$ & Non-anemic $(\mathbf{n = 1 9 3 )}$ & & \\
\hline MCH(pg) & $87.03 \pm 27.84$ & $88.94 \pm 8.22$ & 0.144 & NS \\
\hline MCHC (g/dl) & $27.42 \pm 6.18$ & $28.53 \pm 3.15$ & 0.018 & S \\
\hline
\end{tabular}

NS = Non-significant, $\mathrm{S}=$ Significant

Table 5 shows the comparison of red blood indices in the anemic and non anemic group. The mean value of MCV in the anemic group was $87.03 \pm 27.84$; $\mathrm{MCH} 27.42 \pm 6.18$; and MCHC was $61.30 \pm 21.30$.

S.Fe mean value was $61.30 \pm 21.30$. In the non-anemic group, MCV was $88.94 \pm 8.22$; $\mathrm{MCH}$ was $28.53 \pm 3.15$ and MCHC was 29.95 \pm 2.95 .
S.Fe $(\mathrm{mcg} / \mathrm{dL})$ mean value in the anemic group was $61.30 \pm 21.30$ and non-anemic group was 77.03 \pm 13.15 . Mean TIBC (mcg/dL) levels in anemic group was $319.02 \pm 90.68$ and non-anemic group was 233.54 \pm 43.01 .

The incidence of preterm delivery in the anemic group was $14.46 \%$ and in the non-anemic group was $2.07 \%$. 
The percentage of patients with $\mathrm{PPH}$ was 9.06 in the anemic group and 2.07 in the non-anemic group.

Table 6: Comparison of anemic and non-anemic groups for iron studies.

\begin{tabular}{|c|c|c|}
\hline & S. Fe (mcg/dL) & TIBC (mcg/dL) \\
\hline Anemic $(n=574)$ & $61.30 \pm 21.30$ & $319.02 \pm 90.68$ \\
\hline $\begin{array}{l}\text { Non-anemic } \\
(n=193)\end{array}$ & $77.03 \pm 13.15$ & $233.54 \pm 43.01$ \\
\hline $\mathrm{p}$-value & $<0.0001$ & $<0.0001$ \\
\hline Remarks & S & $S$ \\
\hline
\end{tabular}

Table 7: Adverse maternal outcome in anemic and non-anemic group.

\begin{tabular}{|c|c|c|c|c|}
\hline \multirow[b]{2}{*}{$\begin{array}{l}\text { Adverse } \\
\text { maternal } \\
\text { outcome }\end{array}$} & \multicolumn{2}{|c|}{ No. of patients (\%) } & \multirow[b]{2}{*}{ p-value } & \multirow[b]{2}{*}{ Remarks } \\
\hline & $\begin{array}{l}\text { Anemic } \\
(n=574)\end{array}$ & $\begin{array}{l}\text { Non- } \\
\text { anemic } \\
(n=193)\end{array}$ & & \\
\hline Preterm & $\begin{array}{l}83 \\
(14.46)\end{array}$ & $4(2.07)$ & $<0.0001$ & $\mathrm{~S}$ \\
\hline $\mathrm{PPH}$ & $\begin{array}{l}52 \\
(9.06)\end{array}$ & $4(2.07)$ & 0.044 & $\mathrm{~S}$ \\
\hline $\begin{array}{l}\text { Pre- } \\
\text { eclampsia }\end{array}$ & $\begin{array}{l}54 \\
(9.41)\end{array}$ & $2(1.04)$ & 0.011 & $\mathrm{~S}$ \\
\hline Eclampsia & $2(0.35)$ & $0(0.00)$ & 0.553 & NS \\
\hline $\mathrm{CCF}$ & $\begin{array}{l}10 \\
(1.74)\end{array}$ & $0(0.00)$ & 0.191 & NS \\
\hline Mortality & $3(0.52)$ & $0(0.00)$ & 0.682 & NS \\
\hline $\begin{array}{l}\text { Blood } \\
\text { transfusions }\end{array}$ & $\begin{array}{l}103 \\
(17.94)\end{array}$ & $5(2.59)$ & $<0.0001$ & $\mathrm{~S}$ \\
\hline
\end{tabular}

NS = Non-significant, $\mathrm{S}=$ Significant

The percentage of anemic patients with preeclampsia was 9.41 and in the non-anemic group was 1.04. $0.35 \%$ anemic patients suffered from eclampsia and none in the non-anemic group. $1.74 \%$ patients suffered from CCF in the anemic group as compared to none in the non-anemic group. There were $0.52 \%$ maternal mortalities in the anemic group and none in the non-anemic group. $17.94 \%$ of the patients in the anemic group received blood transfusions in the anemic group as compared to only $2.59 \%$ in the non-anemic group.

Table 8: Group comparison for adverse fetal outcome.

\begin{tabular}{|lllll|}
$\begin{array}{l}\text { Adverse } \\
\text { fetal } \\
\text { outcome }\end{array}$ & $\begin{array}{l}\text { No. of patients }(\%) \\
\text { Anemic } \\
(\mathbf{n = 5 7 3 )}\end{array}$ & $\begin{array}{l}\text { Non- } \\
\text { anemic } \\
(\mathbf{n = 1 9 2})\end{array}$ & p-value & Remarks \\
\hline IUFD & $55(9.60)$ & $2(1.04)$ & 0.011 & $\mathrm{~S}$ \\
\hline IUGR & $48(8.38)$ & $3(1.56)$ & 0.032 & $\mathrm{~S}$ \\
\hline NICU & $97(16.93)$ & $3(1.56)$ & $<0.0001$ & $\mathrm{~S}$ \\
\hline MSL & $73(12.74)$ & $2(1.04)$ & $<0.0001$ & $\mathrm{~S}$ \\
\hline
\end{tabular}

NS = Non-significant, $\mathrm{S}=$ Significant

Among the adverse fetal outcomes, $9.60 \%$ of the anemic group had intrauterine deaths and only $1.04 \%$ among the non-anemic group. $8.38 \%$ fetuses of the anemic group suffered from intrauterine growth restriction as compared to $1.56 \%$ in the non-anemic group. In the anemic group, $16.93 \%$ of the babies were admitted in NICU while only $1.56 \%$ in non-anemic group. $12.74 \%$ of the anemic patients had meconium stained liquor as compared to $1.04 \%$ in the non-anemic group.

Table 9: Group comparison for fetal weight (kg's).

\begin{tabular}{|c|c|c|c|c|}
\hline \multirow{2}{*}{$\begin{array}{l}\text { Fetal } \\
\text { weight } \\
\left(\mathrm{kg}^{9} \mathrm{~s}\right)\end{array}$} & \multicolumn{2}{|c|}{ No. of patients (\%) } & \multirow[b]{2}{*}{ p-value } & \multirow[b]{2}{*}{ Remarks } \\
\hline & $\begin{array}{l}\text { Case } \\
(n=574)\end{array}$ & $\begin{array}{l}\text { Control } \\
(n=193)\end{array}$ & & \\
\hline $\begin{array}{l}\text { Low birth } \\
\text { weight } \\
(<2.5 \mathrm{~kg})\end{array}$ & $\begin{array}{l}181 \\
(31.53)\end{array}$ & $13(6.74)$ & $<0.0001$ & $\mathrm{~S}$ \\
\hline Mean \pm SD & $2.58 \pm 0.49$ & $2.97 \pm 0.41$ & $<0.0001$ & $\mathrm{~S}$ \\
\hline
\end{tabular}

Among the anemic group, 181 patients i.e. $31.53 \%$ had low birth weight infants and only 13 i.e. $6.74 \%$ in the non-anemic group. The men birth weight in the anemic group was $2.58 \pm 0.49$ and in the non-anemic group was $2.97 \pm 0.41$.

Table 10: Group comparison for APGAR scores.

\begin{tabular}{|lllll|}
\hline \multicolumn{4}{|l}{$\begin{array}{l}\text { No. of patients }(\%) \\
\text { A/S at 1 min }\end{array}$} & \multicolumn{2}{l|}{ A/S at 5 min } \\
\hline A/S & $\begin{array}{l}\text { Anemic } \\
(\mathbf{n = 5 7 4})\end{array}$ & $\begin{array}{l}\text { Non- } \\
\text { anemic } \\
(\mathbf{n = 1 9 3})\end{array}$ & $\begin{array}{l}\text { Anemic } \\
(\mathbf{n = 5 7 4})\end{array}$ & $\begin{array}{l}\text { Non- } \\
\text { anemic } \\
(\mathbf{n = 1 9 3})\end{array}$ \\
\hline$<7$ & $68(11.85)$ & $8(4.15)$ & $48(8.38)$ & $2(1.04)$ \\
\hline$>7$ & 505 & 184 & 525 & 190 \\
$(88.15)$ & $(95.85)$ & $(91.62)$ & $(98.96)$ \\
\hline $\begin{array}{l}\text { Mean } \\
\text { A/S }\end{array}$ & $9.22 \pm 2.27$ & $9.79 \pm 1.00$ & $9.37 \pm 2.12$ & $9.92 \pm 0.57$ \\
\hline p-value & 0.040 & & 0.011 & \\
\hline Remarks & $\mathrm{S}$ & & $\mathrm{S}$ & \\
\hline
\end{tabular}

NS = Non-significant, $\mathrm{S}=$ Significant

The percentage of anemic patients with APGAR score $<7 / 10$ at 1 minute was 11.85 and in the non-anemic group was 4.15. Mean APGAR score in the anemics at $1 \mathrm{~min}$ was 9.22 \pm 2.27 and in the non-anemic group was 9.92 \pm 0.57 . APGAR scores at 5 min were $<7 / 10$ in 48 patients i.e. in $8.38 \%$ in the anemic group and in 2 patients i.e. $1.04 \%$ in the non-anemic group.

\section{DISCUSSION}

Maternal anemia in pregnancy is commonly considered a risk factor for poor pregnancy outcome such as preterm delivery, low birth weight, intrauterine growth restriction.

In present study, the prevalence of anemia in the women attending SMGS hospital in third trimester of pregnancy was found to be $74.83 \%$. This finding is in correlation with the Task Force Study of ICMR in which the prevalence of anemia in Indian pregnant women was found to be $88 \% .^{8}$ DLHS-2 on RCHalso showed that the prevalence of anemia among pregnant women is high 
(96.2\%). ${ }^{9}$ Thus, prevalence of anemia in pregnant woman is very high.

While studying the age pattern of the pregnant women it was observed that the majority of women in both the groups belonged to 20-25 years age group which is the common reproductive age group; $51.57 \%$ in the anemic group and $50.78 \%$ in the non-anemic group. Mean age group of the anemic group was $25.84 \pm 4.02$ and the nonanemic group 25.91 \pm 4.19 ; difference was statistically not significant. So, in present study age was not a risk factor for anemia. Verhoeff FH et al and Owais MA et al had similarly concluded in their study that age was no longer associated with increased risk of anemia when adjusted with gravidity. ${ }^{10,11}$

As seen in Table 3, in the anemic group, proportion of multigravida was more i.e. $69.33 \%$ as compared to primigravida which was $30.66 \%$. This is because with increasing number of pregnancies the mothers become depleted of their iron stores. Many of them never have full regained a good blood picture, and anemia may persist, and worsens with subsequent pregnancies. This was consistent with the studies of Mann LI et al and Viengsakhone L et al, which showed that parity is a significant risk factor for low birth weight infant. ${ }^{12,13}$

Mean maternal hemoglobin of women in anemic group was $9.20 \pm 1.81 \mathrm{gm} / \mathrm{dl}$ and in the non-anemic group was $11.69 \pm 0.68 \mathrm{gm} / \mathrm{dl}$. On examination of peripheral blood film as shown in Table 4, maximum women in the anemic group had microcytic hypochromic blood picture $(47.56 \%)$. The other types of blood pictures seen were macrocytic $(7.32 \%)$ and dimorphic $(0.52 \%)$. In the nonanemic group, $75.65 \%$ of the women were normocytic normochromic. The difference was statistically significant.

Among the red blood indices, the mean value of $\mathrm{MCV}$, $\mathrm{MCH}$ and $\mathrm{MCHC}$ in the anemic group were lower than in the non-anemic group and the difference was statistically significant. Mean maternal serum iron levels were lower in the anemic group than in the non-anemic group; the difference being statistically significant. Also, the mean total iron binding capacity in the anemic group was higher than in the non-anemic group which was also statistically significant. Thus, the predominant blood picture among the anemic patients was microcytic hypochromic with decreased red cell indices; decreased serum iron levels and increased TIBC suggesting iron deficiency anemia.

Rangnekar AG et al, revealed that microcytic hypochromic anemia was more prevalent suggesting nutritional inadequacy as a cause of anemia. ${ }^{14}$ Milman $\mathrm{N}$ et al, had also concluded in his study that iron deficiency anemia is the most common type of anemia in pregnant women. ${ }^{15}$ The patients in the anemic and non-anemic group were compared for the maternal and the fetal outcomes.
Table 7 shows the comparison of the percentage of adverse maternal outcomes in anemic and non-anemic groups. The percentage of preterm labor in the anemic group was $14.46 \%$ and $2.07 \%$ in the non-anemic group which was statistically significant. The percentage of incidence of postpartum hemorrhage was $9.06 \%$ among the anemics as compared to $2.07 \%$ among non-anemic, which also was statistically significant. The percentage of anemic patients with pre-eclampsia was also significantly increased i.e. $9.41 \% \mathrm{v} / \mathrm{s} 1.04 \%$ among non-anemics. The difference in the incidence of eclampsia, however, was not statistically significant $(0.35 \% \mathrm{v} / \mathrm{s} \quad 0.0 \%) .1 .74 \%$ of the anemics patients suffered from congestive cardiac failiure as compared to none in the non-anemic group the difference being statistically non-significant.

All women in anemic group with severe anemia received blood transfusion. In the non-anemic group only five women received blood transfusion to recover the blood loss in traumatic PPH whereas percentage of blood transfusion in anemic group was 17.94 which was statistically significant.

Naushaba $\mathrm{R}$ et al, concluded that in the anemic group, preterm delivery was in $56.25 \%$ and $\mathrm{PPH}$ in $4.1 \% .^{16}$ Maternal death occurred in $0.9 \%$. All these were significantly higher in women of anemic group as compared to the normal hemoglobin group.

Also, the results of present study were comparable with the study performed by Ghimire et al, in which it was concluded that there was an increased risk of pregnancy induced hypertension, preterm labor, and postpartum hemorrhage among the anemic group. ${ }^{17}$ However there was no difference in maternal mortality among study groups.

In their study, Jain $\mathrm{P}$ et al, also found a significant correlation between anemia and development of preeclampsia, eclampsia, and preterm labor $(\mathrm{P}$ value $<0.05) .{ }^{18}$ The percentage of patients with intrauterine fetal death among the anemics was 9.60 and among the non-anemics it was $1.04 \%$ and this difference was statistically significant.

Sangeeta VB et al, observed that anemic patients had increased number of IUFDs. ${ }^{5}$ After statistical analysis of the impact of maternal anemia on IUGR, it was found that the risk of IUGR increased significantly with the severity of anemia i.e. $8.38 \%$ in the anemic group v/s $1.56 \%$ in the non-anemic group.

Bakhtiar UJ et al, observed 1.7 times greater risk of IUGR in anemic group as compared to non-anemic group. ${ }^{19}$ The percentage of baby of patients with NICU admissions among the anemics was $16.93 \% \mathrm{v} / \mathrm{s} 1.56 \%$ in the non-anemic group and this was also statistically significant. 
Sangeeta VB et al, observed significantly higher rate of NICU admissions in anemic group as compared to nonanemic group. ${ }^{5}$ While comparing the presence of meconium stained liquor among the anemics and nonanemics,it was found that $12.74 \%$ in the former had MSL as compared to $1.04 \%$ in the latter and this differnce was statistically significant.

Anjanappa B et al, had similarly reported the presence of Meconium stained liquor to be more in anemic mothers ( $\mathrm{p}<0.0227$ ) with RR 2.34. ${ }^{20}$ After statistical analysis of the impact of maternal anemia on birth weight it was found that risk of low birth weight increased significantly i.e. $31.53 \%$ in the anemic group v/s $6.74 \%$ in the nonanemic group. The mean birth weight was $2.58 \pm 0.49 \mathrm{~kg}$ in anemic group which was lower than $2.97 \pm 0.41$ in the non-anemic group; difference was statistically significant $(\mathrm{P}<0.0001)$.

Kidanto HL et al, also observed increased risk of low birth weight with severity of anemia with OR of 1.2, 1.7 and 3.8 with mild, moderate and severe anemia respectively compared with women with normal $\mathrm{Hb}$ levels. ${ }^{21}$ Owais MO et al, observed significantly higher number of low birth weight in anemic group as compared to non-anemic group. ${ }^{11}$

After statistical analysis of the impact of maternal anemia on APGAR score at 1 and 5 minutes, it was found that the risk of APGAR score $<7$ was increased significantly in the anemic group as compared to the non-anemic group i.e. $11.85 \% \mathrm{v} / \mathrm{s} 4.15 \%$. The mean APGAR score in the anemic group was $9.22 \pm 2.27$ at 1 minute and $9.79 \pm 1.00$ at 5 minutes with a p-value of 0.040 , while the mean APGAR scores in the non-anemic group was $9.37 \pm 2.12$ at 1 minute and $9.92 \pm 0.57$ at 5 minutes with a p-value of 0.011 ; the difference being statistically significant.

Sangeeta VB et al, concluded that the newborns of anemic mothers had 1.6 times increased risk of having an APGAR score of $<5$ at 1 min. $^{5}$ Thus, this has been highlightened that maternal anemia is one of the most common and avoidable risk factors for adverse maternal and perinatal outcome.

Anemia is directly related to low birth weight, low APGAR scores at birth, preterm delivery, IUGR, NICU admissions as well as IUFD. In the mother, it is a significant risk factor for preterm delivery, pre-eclampsia, and post-partum hemorrhage. The most common type of anemia is nutritional, of which iron deficiency is the most prevalent type. A simple and effective strategy of supplementing the mother with iron and proper antenatal care could avert so many adverse consequences to the mother and the fetus.

So, it needs to be emphasized that correction of iron deficiency still remains one of the most important step towards better obstetrical care in developing country like ours. These measures are affordable and easily available in our country and by effective implementation of these we can save many lives of both mother and child.

Funding: No funding sources

Conflict of interest: None declared

Ethical approval: The study was approved by the Institutional Ethics Committee

\section{REFERENCES}

1. Sharma JB. Nutritional anemia during pregnancy in non industrial countries. Progress in Obstet Gynecol. Studd J. 2003;15:103-122.

2. Marahtta R. Study of anemia in pregnancy and its outcome in Nepal Medical College Teaching Hospital, Kathmandu, Nepal. Nepal Med Coll J. 2007 Dec;9(4):270-4.

3. Kumar J, Asha N, Murthy S, Sujatha MS, Manjunath VG. Maternal Anemia in Various Trimesters and its Effect on Newborn Weight and Maturity: An Observational Study. Int J Prev Med. 2013 February; 4(2):193-9.

4. Gregory P, Taslim A. Health Status of the Pakistani population: a health profile and comparison with the United States. Am J Public Health. 2001;91:93-8.

5. Sangeeta VB. Maternal anemia and neonatal outcome. Sch J App Med Sci. 2014;2(1C):303-9.

6. Rani KU, Gupta J, Gupta R, Aggarwal KC. Maternal anemia and its severity: an independent risk factor for preterm delivery and adverse neonatal outcome. Int J Reprod Contracept Obstet Gynecol. 2014;3(2):325-9.

7. Batar A, Salvi A, Saini L, Agarwal S, Rajoria L, Mital P. Maternal and Perinatal outcome of Pregnancy with Severe Anemia. Int J Biomed Adv Res. 2015;6(08):611-6.

8. Indian Council of Medical Research. Evaluation of National Nutritional Anemia Prophylaxis Programme. TASK Force study. New Delhi: ICMR 1989.

9. DLHS on RCH. Nutritional status of children and prevalence of anemia among children, adolescent girls and pregnant women. 2002-2004.

10. Verhoeff FH, Barbin BJ, Chimsuku L. An analysis of determinants of anemia in pregnant women in rural Malawi- a basis for action. Annal Tropic Med Parasitol. 1999;93(2):119-33.

11. Owais MA, Kalsoom U. Effect of maternal anameia on birth weight. J Ayub Med Coll Abbottabad. 2011;23(1).

12. Mann LI, Tejani NA, Weiss RR. Antenatal diagnosis and management of small for gestational age fetus. Am J Obstet Gynecol. 1974;120:995-1004.

13. Viengsakhone L, Yoshida Y, Harun-Or-Rashid M, Sakamoto J. Factors affecting low birth weight at four central hospitals in vientiane, Lao PDR. Nagoya. J Med Sci. 2010;72:51-8.

14. Rangnekar AG, Darbari R. Fetal outcome in pregnancy anemia. J Obstet Gynecol India. 1993April;43(2):172-6. 
15. Milman N, Bergholt T, Byg KE, Erikson L, Gradual $\mathrm{N}$. Iron status and balance during pregnancy: A critical reappraisal of iron supplementation. Acta Obstet Gynecol Scand. 1999;78:749-57.

16. Naushaba R, Uddin SF. Maternal anemia impact on maternal and perinatal outcome. Int $\mathrm{J}$ Medic Med Sci. 2013;3(1):328-331.

17. Ghimire RH. Maternal and fetal outcome following severe anemia in pregnancy. J Nobel Med Co. 2013;2(3):22-6.

18. Jain P, Kural M, Tulika J. Maternal and fetal outcome in cases of severe Anemia with pregnancy in rural setup. Int J Med Appl Sci. 2013;2(3):318-33.

19. Bakhtiar UJ, Khan Y, Nasar R. Relationship between maternal hemoglobin and Perinatal outcome. RMJ. 2007;32(2):102-4.
20. Anjanappa B, Radhika BH, Nataraja HG, Ramaiah R, Sathya P. Maternal hemoglobin and perinatal outcome. Int J Reprod Contracept Obstet Gynecol. 2015;4(5):1335-8.

21. Kidanto HL, Mogren I, Lindmark G, Massawe S, Nystrom L. Risks forpreterm delivery and low birth weight are independently increased byseverity of maternal anemia. S Afr Med J. 2009;99(2):98-102.

Cite this article as: Kaul I, Sunil I, Gupta A.

Maternal haemoglobin and perinatal outcome in a tertiary care hospital in Jammu city, India. Int J Reprod Contracept Obstet Gynecol 2017;6:5060-6. 